University of Michigan Law School

University of Michigan Law School Scholarship Repository

Law \& Economics Working Papers

$5-19-2020$

\title{
Taxes in the Time of Coronavirus: Is It Time to Revive the Excess Profits Tax?
}

\author{
Reuven S. Avi-Yonah \\ University of Michigan Law School, aviyonah@umich.edu
}

Follow this and additional works at: https://repository.law.umich.edu/law_econ_current

Digipalrt of the Law and Economics Commons, Public Law and Legal Theory Commons, and the Tax Law Cemmens

Network

\section{Logo}

Working Paper Citation

Avi-Yonah, Reuven S., "Taxes in the Time of Coronavirus: Is It Time to Revive the Excess Profits Tax?" (2020). Law \& Economics Working Papers. 170.

https://repository.law.umich.edu/law_econ_current/170

This Article is brought to you for free and open access by University of Michigan Law School Scholarship Repository. It has been accepted for inclusion in Law \& Economics Working Papers by an authorized administrator of University of Michigan Law School Scholarship Repository. For more information, please contact mlaw.repository@umich.edu. 
TAXES IN THE TIME OF CORONAVIRUS:

IS IT TIME TO REVIVE THE EXCESS PROFITS TAX?

Reuven S. Avi-Yonah

The University of Michigan

\begin{abstract}
A recent NY Times headline summarizes one of the biggest economic impacts of the current pandemic: "Big Tech Could Emerge From Coronavirus Crisis Stronger Than Ever." ${ }^{1}$ At a time when many American citizens and businesses suffer economic damage from the Coronavirus Recession, some corporations see their profits rise dramatically because of the pandemic.
\end{abstract}

Given that most corporations are losing money but some are now earning excess profits due to the crisis, it is time to revive the wartime excess profits taxes that the US successfully deployed in World War 1 (WW1) and Word War 2 (WW2) to prevent the winners from achieving this form of opportunistic unjust enrichment.

This article will first summarize the historical US experience with the excess profits tax (EPT), focusing on its most recent version from 1940 to 1950. It will then analyze how the US could adapt the EPT to current conditions.

\title{
a. The WW2 US EPT. ${ }^{2}$
}

The most recent US EPT was enacted even before the US entered WW2. It was first adopted in 1940, amended in 1941, 1942, 1943, and 1945, and repealed in 1950.

Excess profits taxes are designed to tax the proportion of profits that derives from some external event not of the taxpayer's making. The US excess profits tax was adopted by Congress to "syphon off war profits." It was intended both to address direct profits as well as indirect profits resulting from the war, and the tax rate was set at $95 \%$. This made the definition of normal profits crucial, since those profits would only be taxed at the regular corporate rate (currently $21 \%$ ). Any profit above normal profit was deemed to be excess profits.

\footnotetext{
${ }^{1}$ https://www.nytimes.com/2020/03/23/technology/coronavirus-facebook-amazonyoutube.html.

2 This description of the WW2 EPT is based on Nuccio, Timothy, Substance over Form: Creditability of the 1997 U.K. Windfall Tax as an Excess Profits Tax Under I.R.C. § 901 (July 1, 2012). Transnational Law \& Contemporary Problems, 2013.
} 
The calculation of the excess profits tax base began not with gross income but with net income as shown on the corporate tax return. This number was then reduced to create "excess profits tax net income." The reduction removed certain items like long-term capital gains and losses, income from discharge of indebtedness, and income from recovering bad debts incurred before the war.

"Excess profits tax net income" was then used to calculate the "excess profits tax credit," which was designed to remove normal profits from the tax base. There were two methods used to calculate the credit: The "average earnings" method and the "invested capital" method.

The average earnings method of calculating the excess profits tax credit began by looking back at the years 1936, 1937, 1938, and 1939 (prior to the war) and determining a monthly base-period average income. The amount of the credit was 95 percent of the "average base period net income," plus 8 percent of the corporation's net capital addition (or minus 6 percent of net capital reduction). The result created a deduction from excess profits tax net income. The average base period net income was deemed to be normal peacetime profit and therefore not subject to the excess profits tax.

Alternatively, the invested capital method assumed that a fair return on invested capital is 8 percent on the first $\$ 5$ million, 6 percent on the next $\$ 5$ million, and 5 percent on invested capital beyond $\$ 10$ million. Calculating invested capital involved summing all of the cash and property invested in the corporation and all profits prior to the taxable year, then reducing that figure by "all the distributions that have been made to stockholders out of other than earnings and profits," plus 50 percent of current debt. This figure was then multiplied by a ratio of "inadmissible assets" to total current assets, which removes credit allowance for partially or completely tax-exempt assets (such as tax-exempt bonds and stock in corporations producing exempt dividends). The idea was that a "taxpayer should be entitled to a reasonable allowance on its invested capital before being subjected to the excess profits tax."

Finally, the sum of the excess profits tax credit, any carry-back or carry-forward of unused credits, and a de minimis exemption was deducted from excess profits tax net income. The result was "adjusted excess profits tax net income," which was taxed at $95 \%$. However, the total average effective tax rate (of the normal corporate tax applied to the credit amount and the EPT) could not exceed $80 \%$.

\section{b. A Modern EPT?}

If Congress wanted to impose a modern excess profits tax, how should it go about it?

Given the diversity of the corporations that are likely to profit from the pandemic and the fact that most of them are not engaged in capital intensive activities, the tax should use the average earnings method based on 2016, 2017, 2018 and 2019. 
In addition, using net (taxable) income as the base is problematic because many highly profitable corporations can reduce or eliminate their tax liability by using deductions for tax purposes but not for book purposes. For example, Amazon paid little tax in 2019 because it (a) expenses physical equipment like servers and warehouses under the TCJA, (d) expenses R\&D, and (c) deducts the excess value of its stock over the exercise price of stock options. ${ }^{3}$ Therefore, the tax base should be book income, not taxable income.

The rest of the WW2 methodology can be applied unchanged. Thus, one would for example start with the book income of Amazon for 2020, subtract a credit for $95 \%$ of average 2016-2019 book earnings plus $8 \%$ of R\&D (the main capital investment), and apply a $95 \%$ tax rate to the excess profits. The resulting tax can be reduced by credits for wages of additional employees hired in 2020 to encourage the winners to hire and pay well during the recession.

For example, assume corporation A has $\$ 10$ billion average book income in 2016-2019. In 2020 it has $\$ 20$ billion book income and spends $\$ 3$ billion on R\&D. Its tax liability under the regular corporate tax and the EPT would be calculated as follows:

Step One: Calculate Excess Profits Tax Income: \$20 billion.

Step Two: Calculate Excess Profits Tax Credit: $95 \%$ x $\$ 10$ billion $=\$ 9.5$ billion plus $8 \% x$ $\$ 3$ billion $=\$ 240$ million, total $\$ 9.74$ billion.

Step Three: Deduct Excess Profits Tax Credit from Excess Profit Tax Net Income: \$20 billion minus $\$ 9.74$ billion $=\$ 10.26$ billion.

Step Four: Calculate Excess Profit Tax Liability $\$ 10.26$ x 95\% = \$9.747 billion.

Step Five: Calculate Corporate Tax Liability on "regular" earnings that are not subject to the excess profits tax $\$ 9.74 \times 21 \%=\$ 2.05$ billion.

Step Six: Add the regular corporate tax and the excess profits tax and make sure the total is not more than $80 \%$ of net income.

$\$ 9.747+\$ 2.05=\$ 11.797$ billion total tax. ${ }^{4}$

Effective average tax rate: $13.797 / 20=58.985$.

There are several important anti-avoidance rules that should be adopted to protect the integrity of the EPT.

a. To prevent corporations subject to the EPT from splitting up to reduce their profits below the EPT threshold, mandatory consolidation at the $>50 \%$ level (by vote or value) should be applied, including foreign subsidiaries (to prevent offshore profit

${ }^{3}$ https://finance.yahoo.com/news/why-the-coronavirus-may-not-change-amazons-0federal-tax-rate-114558368.html

${ }^{4}$ Total tax liability is reducible by credit for wages of employees hired in 2020. 
shifting). Consolidated returns were in fact first adopted on a mandatory basis in the Revenue Act of 1917 to protect the WW1 EPT. ${ }^{5}$

b. To prevent corporations subject to the EPT from acquiring loss corporations to reduce EPT liability, the section 382 limits should be strictly enforced.

c. To prevent inversions to avoid EPT, section 7874 should be amended to define an inverted corporation as any foreign corporation managed and controlled from the US and to reduce the threshold for defining a foreign corporation as a domestic corporation from $80 \%$ to $50 \%$.

d. To prevent shifting profits over time, any EPT adopted for 2020 should be extended for at least five years after the pandemic is over.

\section{c. Conclusion}

It is unconscionable that some corporations would profit from the current crisis while everyone else suffers. ${ }^{6}$ Moreover, the federal government will be spending trillions to save the economy, and much of this spending would benefit the winners since it will be spent on their services. There is no reason not to use this opportunity to revive the excess profit tax and apply it to profits that derive entirely from the pandemic.

\footnotetext{
${ }^{5}$ See See Avi-Yonah, Reuven S., THE WORST TAX LAW EVER ENACTED? (May 10, 2020), available on SSRN.

${ }^{6} \mathrm{An}$ exception should be adopted for any corporation that produces a successful vaccine or treatment for COVID19 , to incentivize such efforts.
} 